\title{
DINÂMICAS DE EXPANSÃO E VALORIZAÇÃO DESIGUAL DO ESPAÇO DA METRÓPOLE FORTALEZA
}

\section{dynamics of expansion and uneven appreciation space in Metropolis Fortaleza}

\author{
Elizete de Oliveira Santos ${ }^{1}$ \\ Francisco Antonio Carneiro da Silva ${ }^{2}$
}

${ }_{a} a \boldsymbol{a}_{a a}$

\begin{abstract}
Resumo
Esse artigo analisa o processo de constituição da metrópole Fortaleza, enfocando as dinâmicas de expansão urbana (vetores de metropolização) e de valorização desigual do espaço (reforçada pelo planejamento urbano). O texto estrutura-se em duas partes: na primeira, são apresentados os vetores de metropolização em Fortaleza, que comandaram a expansão urbana da cidade e desenharam a atual estrutura da metrópole; na segunda, analisa-se o planejamento urbano no município sede, destacando seu papel da estruturação metropolitana, resultado do descolamento entre o "discurso competente" do planejamento e a realidade das transformações na metrópole.

Palavras-chave:
\end{abstract}

Palavras-chave: metrópole; expansão urbana; Planejamento urbano.

\begin{abstract}
This paper analyzes the process of metropolis Fortaleza constitution, focusing on the urban sprawl dynamics (vectors metropolis) and the appreciation unequal of space (enhanced by urban planning). The structure is in two parts: the first presents the vectors metropolis in Fortaleza, who led the town expansion and designed the current metropolis structure; in the second, analyzes the urban planning in the municipality seat, result of detachment between "responsible speech" of urban planning and the reality of transformations in the metropolis.
\end{abstract}

Key words: Metropolis; Expansion urban; Urban planning.

\section{Resumen}

En este artículo se analiza el proceso de constitución de la metrópoli Fortaleza, centrándose en la dinámica de la expansión urbana (os vectores metropolización) y desigual recuperación de espacio (reforzada por la planificación urbana). La estructura consta de dos partes: la primera presenta los vectores metropolización en Fortaleza, quien dirigió la expansión de la ciudad y diseñó la estructura actual de la metrópoli; en la segunda, se analiza la planificación urbana en la cabecera municipal, destacando su papel estructurante de resultado metropolitana de separación entre el "discurso responsable" y la realidad de la planificación de los cambios en la metrópoli.

Palabras-clave: Metrópoli; Expansión urbana; Planificación urbana.

(1) Doutoranda em Geografia na Universidade Federal do Ceará - Campus do Pici, Bloco 911, CEP 60455-760 - Fortaleza (CE), Brasil. Tel: (+55 85 ) 33669855 - elizeoliver7@yahoo.com.br

(2) Mestrando em Geografia na Universidade Federal do Ceará - Campus do Pici, Bloco 911, CEP 60455-760, Fortaleza (CE), Brasil. Tel: (+55 85) 33669855 - facsjony@yahoo.com.br

\section{aaaa}




\section{INTRODUÇÃO}

No atual contexto mundial, o processo de metropolização do espaço se destaca como estratégia de sobrevida capitalista, ultrapassando o processo de urbanização que caracterizou o capitalismo industrial, sem significar, contudo, que não haja mais o processo de urbanização. Em outros termos, o processo de metropolização do espaço deve ser entendido como uma fase superior da urbanização, sendo a metrópole contemporânea um produto da metamorfose do processo de urbanização (LENCIONI, 2004; 2006; 2011). Ainda para a autora, essa metamorfose metropolitana tem como eixo norteador o processo de metropolização do espaço, intrinsecamente relacionado à reestruturação produtiva que tem transformado a metrópole em instrumento primaz da reprodução do capital, em virtude da nova relação que se estabelece entre o capital imobiliário e o financeiro (LENCIONI, 2011).

[...] é o processo de metropolização que se constitui numa determinação histórica da sociedade contemporânea. Esse processo é expressão de uma nova época, na qual a metrópole se coloca ao mesmo tempo como uma condição para a reprodução do capital, um meio utilizado para a sua reprodução e, ainda, um produto do próprio capital. Isso, num quadro de profundas alterações na dinâmica do capital imobiliário e financeiro, como estratégias de renovação da reprodução capitalista. (LENCIONI, 2011, p. 136)

Nesse sentido, entende-se a metropolização como reprodução ampliada da metrópole. Esse entendimento parte da realidade concreta, sendo uma nova leitura que dialoga com a ideia de diversos autores, destacando-se: Ascher (1998, p. 15), segundo o qual a metropolização é "um fenômeno que ultrapassa a metrópole"; Lencioni (2006, p. 47), para quem "enquanto a ideia de metrópole se relaciona à de cidade, a de metropolização a ultrapassa"; e Amora (1999, p. 33), asseverando que "a metropolização, como forma de organização do território, corresponde a um processo ou algo que ultrapassa a metrópole".

O processo de metropolização do espaço, mais intenso e complexo que a urbanização do espaço, se expressa na intensificação e multiplicidade dos fluxos de pessoas, mercadorias e informações, assim como pelo crescimento do número de cidades conurbadas, evidenciadas na continuidade da área construída e nos limites municipais tornados difusos. Além disso, caracteriza-se pela expansão territorial do aglomerado metropolitano e pela extensão e densificação territorial da concentração das infraestruturas, tanto públicas quanto privadas (LENCIONI, 2011). A fluidez de pessoas, mercadorias e informações são viabilizadas pela produção de infraestruturas materiais e imateriais, superpondo uma escala topológica à escala topográfica que caracterizava as cidades. Desse modo, a densidade das redes (materiais e imateriais) se revela elemento fundamental no papel desempenhado pelas metrópoles, contribuindo para desenhar as novas relações de centralização da gestão e controle do território, bem como novas estruturas de hierarquização urbana.

Como resultado das relações conflituais e contraditórias entre a escala topográfica e a escala topológica, a metrópole se apresenta como forma espacial dotada de dinamismo, fluxos materiais e imateriais, concentração e dispersão, homogeneização e fragmentação. Segundo Lencioni (2006),

Metrópole constitui uma forma urbana de tamanho expressivo, quer relativo ao número de sua população, quer em relação à sua estrutura territorial; possui uma gama diversa de atividades econômicas, o que a constitui como um ponto de grande densidade de emissão e recepção de fluxos de informação e comunicação, fator que costura um nó significativo de redes, sejam de transporte, informação, cultura, inovação, consumo, poder e, principalmente, a concentração de serviços públicos e privados (LENCIONI, 2006, p. 45).

As metrópoles são centros do poder econômico, social e político. São formas espaciais capazes de polarizar o território nas escalas nacional, regional e local. Entre as características dos aglomerados metropolitanos, destacam-se a organização funcional dos espaços; a concentração/distribuição de população, produto e rendimentos; os fluxos de mercadorias, população e serviços; as condições de infraestrutura urbana; os processos de ocupação territorial; as articulações de poder; entre outras (RIBEIRO, 2009; 2012).

Destarte, a metrópole é a cidade principal de uma região, nó de comando e coordenação de uma rede urbana que não só se destaca pelo tamanho populacional e econômico, como também pelo desempenho de funções 
complexas e diversificadas (multifuncionalidade), e que estabelece relações econômicas com várias outras aglomerações.

Segundo estudo do Observatório das Metrópoles (RIBEIRO, 2012), no território brasileiro há 51 Regiões Metropolitanas, três Regiões Integradas de Desenvolvimento e cinco Aglomerações Urbanas oficialmente instituídas. Entre as RMs, apenas 12 têm natureza metropolitana, conforme o estudo Região de Influência de Cidades/REGIC 2007 (IBGE, 2008), agregando 28\% do total de 945 municípios envolvidos: São Paulo, considerada Grande Metrópole Nacional; Rio de Janeiro e Brasília, consideradas Metrópoles Nacionais; e Belém, Belo Horizonte, Curitiba, Fortaleza, Goiânia, Manaus, Porto Alegre, Recife e Salvador, como Metrópoles Regionais.

Em termos de institucionalização das regiões metropolitanas no Brasil, podem ser destacados dois grandes períodos: o primeiro se dá na década de 1970, com a criação das primeiras oito RMs do país, na esteira da centralização de poder na esfera federal durante o Período Militar; o segundo se dá após a Constituição de 1988, que atribuiu aos estados a competência de criação de RMs, mas contraditoriamente tirou a legitimidade dos estados para coordenar as ações metropolitanas ao reconhecer os municípios como entes federados dotados de autonomia política (SANTOS JUNIOR, 2009). As RMs criadas no segundo período têm regulação bastante diversificada, havendo estados que, tendo mais de uma região, conferem tratamento diferenciado a cada uma. Além da criação de novas regiões, os estados passaram a incluir novos municípios em regiões criadas por leis federais na década de 1970, expandindo as RMs para além dos limites efetivamente metropolitanos. A falta de critérios claros para definir a condição metropolitana dos municípios, que prevalece na maioria dos casos, torna a discussão do tema vulnerável a fortes pressões políticas, podendo resultar na constituição de regiões extremamente heterogêneas quanto ao grau de integração desses municípios ao fenômeno metropolitano, o que impõe muitos limites à efetiva gestão metropolitana.

No caso da metrópole Fortaleza, a efetiva metropolização se deu posteriormente à sua institucionalização enquanto Região Metropolitana pela Lei Complementar n 14, de 8 de junho de 1973, objetivando o planejamento integrado do desenvolvimento econômico e social, bem como a articulação entre municípios da região para a execução de serviços de interesse comum. Criada de forma compulsória no bojo da centralização política que caracterizou a Ditadura Militar, a RMF foi composta inicialmente pelos municípios Fortaleza, Aquiraz, Maranguape, Pacatuba e Caucaia. Na década de 1970, ainda não existiam indícios de complementaridade nas funções dos municípios da RMF, nem continuidade da mancha urbana ou de fluxos de movimentos pendulares significativos, ou seja, a metropolização ainda não havia se manifestado (SILVA, 2009). Somente na década de 1980, iniciou-se a conurbação no vetor sudoeste de expansão metropolitana, com os municípios de Caucaia e Maracanaú, que até hoje são os municípios mais integrados à metrópole.

\section{A CONFIGURAÇÃO TERRITORIAL DA RMF}

A configuração territorial da RMF apresentou muitas transformações nos últimos 40 anos, ampliando-se em função de desmembramentos com a emancipação de vários distritos (Eusébio, Guaiúba, Itaitinga e Maracanaú) e da agregação de outros municípios à RMF, resultando em conjunto dispondo de temporalidades e espacialidades diferenciadas, composto por 15 municípios (Figura 1).

A realidade socioespacial da RMF confirma o descompasso entre os recortes institucionais das regiões metropolitanas e a efetiva configuração do recorte de sua aglomeração, como aponta o estudo do Observatório das Metrópoles (RIBEIRO, 2009). Poucos municípios são efetivamente integrados à metrópole, de modo que a porção intraurbana da RMF é muito compacta, formada pelos municípios contíguos à metrópole (Fortaleza, Maracanaú, Caucaia, Pacatuba, Eusébio e Aquiraz). A centralidade exercida por Fortaleza no conjunto metropolitano se expressa com clareza nas ligações rodoviárias. Os eixos viários estruturantes da RMF são formados por rodovias e ferrovias, cuja configuração radial concêntrica superposta à malha em xadrez remonta ao processo de formação da capital no século XIX. Os antigos caminhos de escoamento da produção agroexportadora e dos fluxos migratórios transformaram-se nos principais eixos de circulação e integração metropolitana, reforçando a centralidade da cidade polo. 


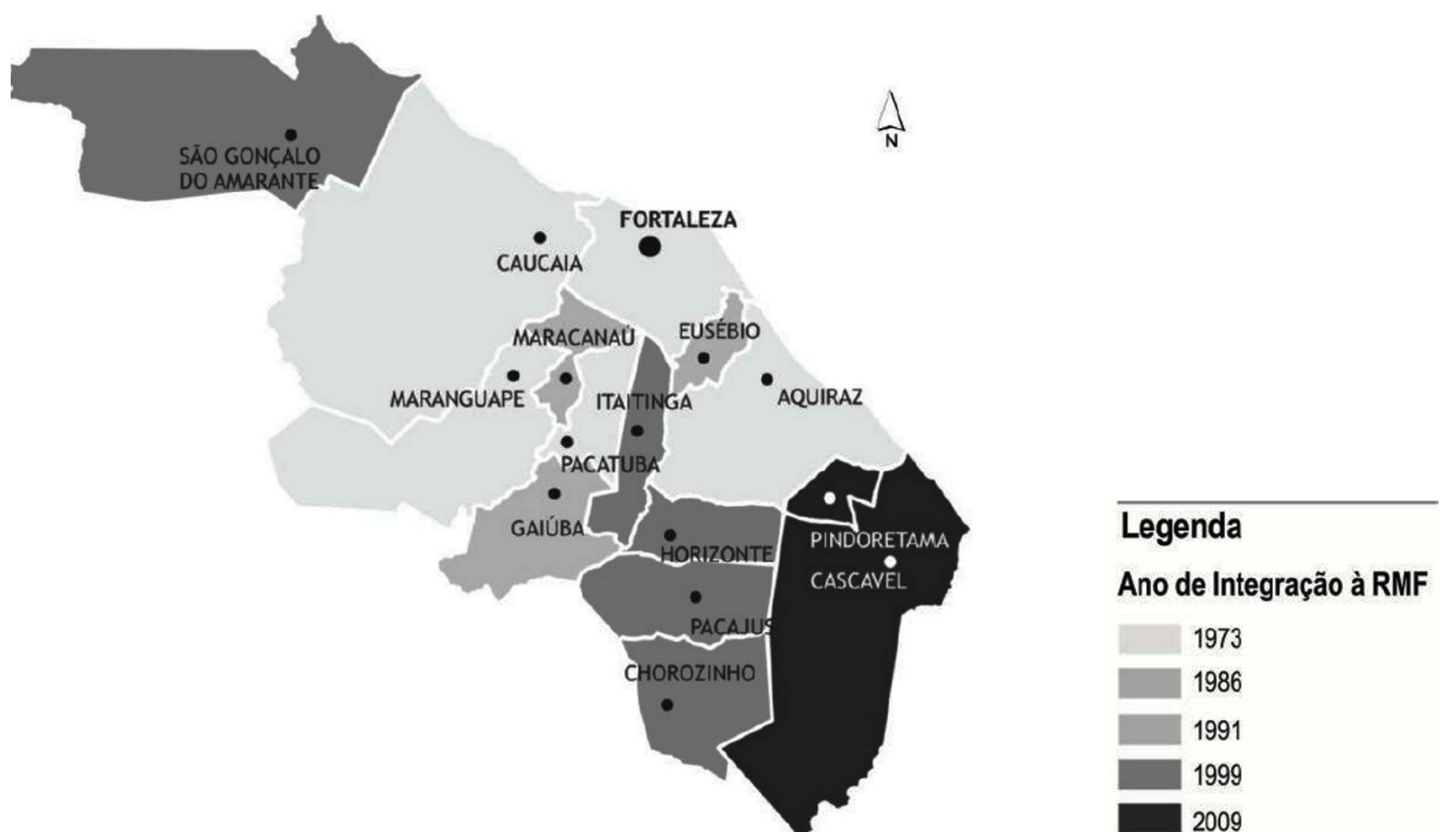

]Figura 1 - Evolução institucional dos municípios da RMF Fonte: RUFINO, 2012

Esse artigo tem como objetivo discutir o processo de constituição da metrópole Fortaleza, enfocando as dinâmicas de expansão urbana (vetores de metropolização) e de valorização desigual do espaço (reforçada pelo planejamento urbano). O texto está estruturado em duas partes, além desta Introdução e das Considerações finais: na primeira, são apresentados os vetores de metropolização em Fortaleza, que comandaram a expansão urbana da cidade e desenharam a atual estrutura da metrópole; na segunda, analisa-se o planejamento urbano no município sede, destacando seu papel da estruturação metropolitana, resultado do descolamento entre o "discurso competente" do planejamento e a realidade das transformações na metrópole.

\section{VETORES DE METROPOLIZAÇÃO EM FORTALEZA}

A história da produção do espaço em Fortaleza já foi discutida por vários cientistas sociais (CASTRO, 1977; COSTA, 1988, 2009; DANTAS, 2009; FUCK JUNIOR, 2002; PEQUENO, 2002; SILVA, 1992, 2009; SILVA, 1999; SOUSA, 2009). Nesse sentido, não constitui objetivo deste artigo reconstruir detalhadamente essa história, mas partir desses autores e assinalar como a expansão urbana e a valorização fundiária desigual se processaram de forma articulada ao planejamento urbano, embora muitas vezes esse planejamento não tenha passado de discurso ideológico sem efetiva implementação. Para tanto, a discussão será desenvolvida com base nas reflexões dos autores mencionados, cotejadas com a análise dos planos municipais e da estrutura da metrópole a partir dos vetores de metropolização.

Analisando a dinâmica socioespacial da metrópole Fortaleza da atualidade, marcada pela acentuada macrocefalia, é difícil imaginar que até o final do século XVIII, ela era apenas uma pequena vila sem nenhuma expressão econômica, tendo apenas o papel de capital administrativa do Ceará (COSTA, 2009). A hierarquia urbana cearense era relativamente melhor distribuída, destacando-se cidades como Aracati, Icó, Sobral (com função comercial, administrativa e de serviços), Crato (com função agrícola, administrativa e industrial), Camocim, Acaraú (com função comercial e industrial) e Quixeramobim (com função comercial e de serviços). Isso está ligado ao fato de que a formação do território cearense apresentou peculiaridades no contexto do Nordeste, não se desenvolvendo a partir da lógica de estruturação do espaço denominada de rede dendrítica (DANTAS, 2009). Diferentemente, a ocupação do território cearense se deu do sertão para o litoral, seguindo o curso dos rios como eixos de penetração (LIMA, 2005). 
Conforme Dantas (2009), o quadro de isolamento da capital só seria alterado em meados do século XIX, em face de um conjunto de mudanças político-administrativas (independência jurisdicional do Ceará em relação a Pernambuco e à abertura dos portos às nações amigas) e tecnológicas (implantação de ferrovias e de navios a vapor, que impunham vantagens na utilização do porto de Fortaleza para drenagem de mercadorias). É importante lembrar a conjuntura internacional favorável em relação à exportação de algodão cearense diretamente para Inglaterra em virtude da Guerra de Secessão americana, que interrompeu o fornecimento dessa matéria prima. Desde então, houve a reconfiguração da rede urbana, pautando-se na progressiva concentração de fluxos de pessoas, mercadorias e capitais em Fortaleza, enfraquecendo os centros interioranos.

O processo de captura do poder político e econômico do território cearense pela capital, que redundou na fraca rede urbana, foi sintetizado por Souza (2009):

[...] transformações de ordem econômico-social e do sistema de transportes - as ferrovias no final do século passado e durante toda a primeira metade deste século, e as rodovias sobretudo a partir de 1950 - explicam a evolução de Fortaleza. As vias de comunicação vieram facilitar os contatos entre as regiões favorecendo, além das atividades comerciais, um intenso processo migratório para a capital. Este processo migratório, diretamente ligado aos problemas da economia rural do Estado, foi intensificado a partir de 1930, em parte por influência das sucessivas secas $(1932,1952,1958$ e 1970). (SOUZA, 2009, p.69)

Essas transformações na produção social da cidade culminaram com a constituição da metrópole a partir da segunda metade da década de 1970 e, marcadamente, na década de 1980. A aglomeração metropolitana é o resultado acumulado de diferentes vetores de metropolização, relacionados principalmente às atividades produtivas (industrial, turístico, comercial) e às formas de produção de moradia (PEQUENO e MOLINA, 2009).

A industrialização foi o primeiro vetor de metropolização, impulsionada pelos investimentos da SUDENE a partir da década de 1960, que viabilizou a criação do primeiro Distrito Industrial de Fortaleza em Maracanaú, à época distrito de Maranguape. Embora a consolidação desse distrito industrial só tenha ocorrido na década de 1980, ele foi fundamental para a integração dos municípios de Maracanaú e Pacatuba, articulando-se ao vetor habitacional com a construção de conjuntos habitacionais visando o acesso à moradia para os trabalhadores atraídos pelas indústrias e/ou expulsos pelo restrito mercado de terras da capital. $\mathrm{Na}$ década de 1990, transformações econômicas possibilitaram a expansão do setor industrial em eixos e minidistritos ao longo das rodovias federais e estaduais, nos municípios de Horizonte, Pacajus, Pacatuba, Eusébio, Maranguape e Caucaia, vinculada à política estadual de atração de indústrias. Um novo momento da industrialização começa a se delinear com a criação do Complexo Industrial e Portuário do Pecém (CIPP) entre os municípios de Caucaia e São Gonçalo do Amarante, decorrente do projeto modernizante do Governo Estadual.

A indústria enquanto vetor de integração metropolitana apresenta uma estrutura espacial fundada no sistema viário radioconcêntrico, destacando-se as vias regionais CE 060, BR-116, CE 040 e BR-222 (DANTAS, 2009). Na primeira artéria, há o consolidado complexo industrial de Maracanaú (articulando também os municípios Pacatuba e Maranguape). Na segunda artéria, destaca-se a implantação do dinâmico corredor industrial Horizonte-Pacajus, com mais de dez quilômetros ao longo da BR-116, provocando atração sobre a população da zona rural e de cidades próximas. Na terceira artéria, tem-se a presença do Eusébio que recebe importantes sedes de indústrias recentemente. Na quarta e última artéria, aponta-se para investimento do governo do Estado na implantação do Complexo Industrial e Portuário do Pecém, o qual atrai investimentos novos e sinaliza a integração dos municípios de São Gonçalo do Amarante e Caucaia.

O vetor turístico de metropolização está mais vinculado aos municípios litorâneos, nos quais o veraneio marítimo intensifica o processo de incorporação da zona de praia à tessitura urbana da metrópole em constituição (DANTAS e SILVA, 2009). A valorização turística dos espaços litorâneos ganhou força na década de 1990, como um dos eixos de modernização cearense, preconizados nos Planos de Governo da gestão conhecida como "Governo das Mudanças". Na consolidação dessa política de inserção do Ceará no eixo do turismo globalizado, o governo estadual teve como suporte o Programa de Desenvolvimento do Turismo no Nordeste (Prodetur/NE), financiado com recursos do Banco Interamericano de Desenvolvimento (BID), e 
tendo o Banco do Nordeste como órgão executor. Esse programa teve como objetivo melhorar a infraestrutura turística (saneamento, transportes, urbanização e outros) e apoiar projetos de proteção ambiental e do patrimônio histórico e cultural, capacitação profissional e fortalecimento institucional das administrações de estados e municípios da região.

Embora os investimentos do PRODETUR tenham beneficiado todos os municípios litorâneos, os metropolitanos destacam-se pela sua proximidade com a capital, que concentra grande parte dos objetos imobiliários turísticos. A implantação de vias litorâneas (a exemplo da CE 085 - Polo Costa do Sol Poente e CE 040 - Polo Costa do Sol Nascente), as melhorias em aeroportos e os projetos de saneamento estão entre os principais investimentos em turismo que remodelaram o espaço metropolitano. Essas mudanças dão-se na escala nacional e regional, transformando a estrutura espacial, como destacam Dantas e Silva (2009, p.23):

De lógica perpendicular à zona de praia, baseada no porto e na ferrovia, convidando o sertão a se abrir para o mar, tem-se, na contemporaneidade, implantação de lógica paralela apoiada nos aeroportos e vias litorâneas, tornando possível recepção e distribuição dos fluxos turísticos nos municípios costeiros. As capitais se destacam neste processo, concentrando os fluxos e distribuindo-os ao longo de sua área de influência. Reforça-se, na atualidade, a idéia da "vocação turística" do Nordeste, repercutindo em embates no sentido de atrair investimentos e reforçar ideário marítimo.

O vetor turístico de metropolização articula os municípios de Aquiraz (praias Porto das Dunas, Prainha, Presídio, Iguape e Barro Preto), Caucaia (praias Icaraí, Tabuba e Cumbuco), São Gonçalo do Amarante (praias Pecém e Taíba) e, recentemente, Cascavel (praias Caponga, Balbino, Águas Belas e Barra Nova). $\mathrm{O}$ vetor turístico relaciona-se intrinsecamente ao circuito imobiliário, forjando o que pesquisadores têm chamado de "imobiliário turístico" (DANTAS, 2009).

Todavia, é importante salientar que a expansão das atividades turísticas reforçou a ocupação das faixas de praia com casas de veraneio, empreendimentos turísticos e imobiliários, sem alterar as condições de infraestruturas dos núcleos tradicionais, que tendem a permanecer dissociados dessa lógica de crescimento. A inserção recente dos municípios de Cascavel e Pindoretama à RMF reforça as intenções de expansão da ocupação turística e seu caráter urbano descontínuo.

O vetor habitacional de metropolização desdobra-se em três dinâmicas espaciais de produção da moradia, de acordo com os agentes predominantes em cada uma: a das políticas públicas habitacionais, a do circuito imobiliário formal e a da favelização (PEQUENO, 2011).

As políticas habitacionais das décadas de 1970 e 1980 pautavam-se na política nacional de habitação preconizada pelo binômio $\mathrm{SFH} / \mathrm{BNH}$, tendo como marca característica a construção de grandes conjuntos habitacionais em áreas periféricas. Esse momento da expansão urbana da cidade foi fundamental para a metropolização ao integrar principalmente os municípios de Caucaia e Maracanaú, que receberam o maior número de conjuntos, conurbando-se com Fortaleza. Com menor intensidade, também foram construídos conjuntos habitacionais em Maranguape e Pacatuba. Essa forma de produção da moradia foi fundamental para delinear o vetor sudoeste de expansão da metrópole, que conjuga industrialização e construção de grandes conjuntos habitacionais.

Em outros termos, a periferização da localização da produção habitacional pelas políticas públicas foi muitas vezes justificada por sua articulação à política de industrialização, que nesse período procurava fortalecer o Distrito Industrial no município de Maracanaú e planejava a implantação de um distrito industrial em Caucaia. Na prática, esses conjuntos receberam um enorme contingente de população de baixa renda deslocada de Fortaleza contribuindo para o acelerado crescimento demográfico desses municípios sem uma correlação em termos de emprego, impulsionando a mobilidade regular (movimento pendular) motivada por trabalho ou estudo. Nas décadas de 1990 e 2000, houve grande recuo na produção habitacional pelo estado e município, com intervenções pontuais distribuídas em diversas áreas da metrópole, muitas vezes correspondendo à relocação de parte da população assentada em áreas precárias que passam por processos de urbanização.

A atuação do circuito imobiliário formal esteve muito concentrada no setor leste da cidade de Fortaleza (simbolizado pelo bairro de elite Aldeota) até o início da década de 2000, em um cenário de retração dos financiamentos à produção e ao consumo de produtos imobiliários que remonta ao fim do $\mathrm{BNH}$ em meados da década de 1980. Sem o acesso a financiamentos por parte do Estado, as empresas construtoras locais 
restringiram ainda mais o mercado imobiliário, buscando nas camadas de alta renda a demanda solvável para os imóveis de luxo em áreas valorizadas resultado da mobilização de capitais locais. Outra estratégia dos agentes locais do setor imobiliário foi investir no imobiliário turístico, com produtos de alto-padrão voltados ao mercado estrangeiro nos espaços litorâneos valorizados da metrópole. Somente na segunda metade da década de 2000 a estrutura de financiamentos foi alterada em escala nacional, na esteira da recuperação das fontes de financiamento imobiliário (basicamente recursos do SBPE e do FGTS). A abundância de crédito para a produção e o consumo de produtos imobiliários vem alterando profundamente a estrutura da metrópole, com a expansão e valorização imobiliária alcançando espaços da periferia metropolitana (RUFINO, 2012).

O circuito imobiliário formal inicialmente expandiu-se desde a década de 1990 para os municípios de Eusébio (condomínios e loteamentos fechados) e Aquiraz (imobiliário turístico), configurando o eixo sudeste de valorização imobiliária da metrópole, polarizado pela centralidade linear da Av. Washington Soares/CE 040. Mas a partir da segunda metade da década de 2000 (mormente a partir de 2007), inaugura-se um período de grande expansão e valorização imobiliária na metrópole, marcado pelo protagonismo de grandes incorporadoras nacionais que chegaram à Fortaleza, alterando o quadro particular dessa metrópole em que a incorporação articulava-se de forma subordinada à construção civil (RUFINO, 2012). A expansão imobiliária sob o domínio da incorporação tem transformado a estrutura espacial da metrópole, articulando diferentes dinâmicas de valorização imobiliária, como observou Rufino (2012): expansão das áreas de grande valorização, reforçando o eixo leste/sudeste de expansão imobiliária; expansão da valorização da faixa de praia metropolitana (concentrada em Aquiraz e Caucaia); e consolidação da coroa imobiliária do segmento econômico no município de Fortaleza.

Articulada à lógica de expansão e valorização da produção imobiliária residencial se desenvolve uma intensa dinâmica de produção imobiliária comercial, particularmente evidenciada pelo anúncio de um grande número de shoppings centers, cuja localização está diretamente vinculada a áreas que presenciaram grandes mudanças no período.

$\mathrm{Na}$ cidade de Fortaleza, os shoppings centers historicamente se concentraram nas áreas mais valorizadas e em importantes eixos viários. Muitos destes shoppings contribuíram para a intensificação da produção imobiliária em seus entornos, acentuando a valorização destas áreas.

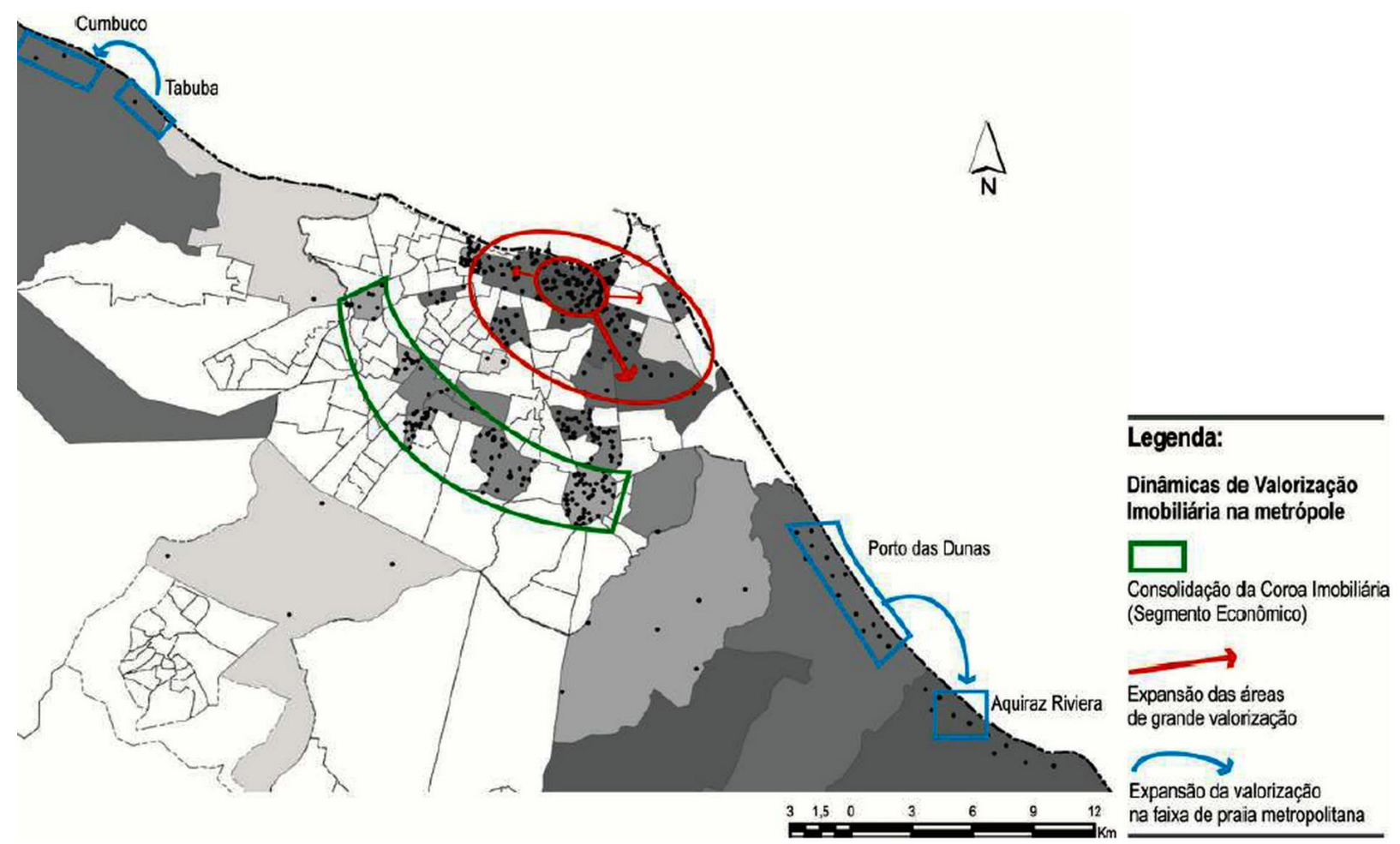

Figura 2 - Dinâmicas de Valorização Imobiliária na metrópole

Fonte: Sinduscon-Ce (Relatório IVV - mês de dezembro de 2010); Base Geometropolis - Observatório das Metrópoles. Organização: RUFINO, 2012. 
Conforme observou Rufino (2012), os shoppings recentemente lançados parecem apresentar nova lógica de localização, diretamente relacionada às mudanças na produção imobiliária formal. Aparecendo em diversas regiões da metrópole, para além da localização no tradicional vetor sudeste de expansão imobiliária, os novos shoppings centers também serão direcionados para novas áreas que se destacaram recentemente por uma intensa valorização imobiliária, nos chamados "bairros emergentes".

A intensificação das dinâmicas imobiliárias parece se consolidar como um dos principais aspectos de atração dos shoppings centers, ao mesmo tempo em que a implantação destes reforça a lógica de valorização. Na atualidade, a relação entre a produção imobiliária residencial e a produção dos shoppings parece ainda mais forte, tanto pela articulação dos usos no desenvolvimento dos empreendimentos, como pelo envolvimento de agente da incorporação da área residencial no desenvolvimento dos projetos de Shoppings Centers, reforçando a ideia de um processo de centralização do capital na produção do espaço.

Finalmente, é preciso destacar que a favelização é o principal processo de produção habitacional em Fortaleza, cuja precariedade se agudiza com a expansão metropolitana. Nos principais mapeamentos de favelas em Fortaleza, realizados em 1973, 1991 e 2011, fica nítido que a expansão do processo de favelização se dá nas sobras de terrenos, seguindo a drenagem natural (rios e lagoas), os eixos ferroviários e a faixa litorânea (dunas e faixa de praia). Assim, à vulnerabilidade social nas favelas, superpõe-se a vulnerabilidade ambiental, delineando espaços de vulnerabilidade socioambiental que tem nas áreas de risco sua maior expressão.

Sintetizando a caracterização da constituição da metrópole, ressalta-se que o tecido urbano contínuo só ultrapassou os limites do município de Fortaleza a partir da década de 1980, na direção sul-oeste, e a partir da década de 2000 na direção leste-sudeste. Mas a produção do espaço nestas duas direções teve significativas diferenças: no vetor sudoeste, a expansão urbana foi induzida pela construção de grandes conjuntos habitacionais ou loteamentos periféricos na direção dos municípios de Maracanaú e Caucaia, ao passo que o vetor sudeste está sendo induzido pela expansão da malha viária regional (e pela concentração de investimentos públicos e privados), atraindo o mercado imobiliário formal. Assim, o vetor de expansão oeste/sudoeste configura-se como área de transbordamento da população de baixa renda para os municípios metropolitanos (Caucaia e Maracanaú), enquanto o vetor de expansão leste/sudeste configura-se como área de transbordamento da população de média e alta renda para os municípios metropolitanos (Eusébio e Aquiraz), como indicou Pequeno (2002).

\section{DISCURSOS E PRÁTICAS DO PLANEJAMENTO URBANO EM FORTALEZA}

Como assinalado anteriormente, dentre os vários instrumentos metodológicos que poderiam ser usados para reconstruir a história de Fortaleza, interessa a esta investigação fazê-lo a partir dos processos de planejamento urbano e da expansão urbana presidida pelos vetores de metropolização.

Quanto ao planejamento urbano, Souza (2002; 2010) e Villaça (1999) são referências importantes reconhecidas pelos estudiosos da temática. Para esses autores, o planejamento urbano é uma atividade do governo municipal que tem uma dimensão técnica e uma dimensão política: técnica por se fundamentar em um saber disciplinar, operatório, representando maneiras ou habilidades especiais de executar algo; política porque, ao definir um projeto de cidade, pode interferir nos processos socioespaciais vigentes, alterando ou não o quadro de hegemonia estabelecido. Para Souza (2002, p.48), o planejamento urbano é uma preparação para a gestão futura, sendo o planejamento e a gestão processos complementares:

Planejamento e gestão não são termos intercambiáveis, por possuírem referenciais temporais distintos e, por tabela, por se referirem a diferentes tipos de atividades. Até mesmo intuitivamente, planejar sempre remete ao futuro: planejar significa tentar prever a evolução de um fenômeno ou, para dizê-lo de modo menos comprometido com o pensamento convencional, tentar simular os desdobramentos de um processo, com o objetivo de melhor precaver-se contra prováveis problemas ou, inversamente, com o fito de melhor tirar partido de prováveis benefícios. De sua parte, gestão remete ao presente: gerir significa administrar uma situação dentro dos marcos dos recursos presentemente disponíveis e tendo em vista as necessidades imediatas. O planejamento é a preparação para gestão futura, buscando-se evitar ou minimizar problemas e ampliar margens de manobra: e a gestão é a efetivação, ao menos em parte (pois o imprevisível e o indeterminado estão sempre presentes, o que torna a capacidade de 
improvisação e a flexibilidade sempre imprescindíveis), das condições que o planejamento e gestão são distintos e complementares.

Para Villaça (1999), o planejamento urbano (em sentido strictu senso) refere-se à ação e ao discurso do Estado sobre a organização e estruturação do espaço urbano. Assim, o autor reconhece três períodos do planejamento urbano no Brasil: (1) 1875-1930: planos de melhoramento e embelezamento; (2) 1930-1990: planos fundados na ideologia da supremacia da razão e da técnica, mediante o discurso competente. São os planos tecnocráticos ou planos-discurso. Divide-se em três subperíodos: (a) 1930-1965: urbanismo e plano diretor; (b) 1965-1971: superplanos; (c) 1971-1992: plano sem mapa; e (3) a partir de 1990: incipiente reação ao período anterior, absorvendo o ideário da Reforma Urbana.

Outra periodização para o planejamento urbano no Brasil foi proposta por Accioly (2008). Essa periodização aplica-se melhor às experiências reproduzidas em Fortaleza, já que a autora tinha nessa metrópole sua referência empírica. Identificam-se cinco períodos quanto às concepções, metodologias aplicadas aos diagnósticos, às diretrizes e aos objetivos das intervenções, ao aparato institucional e mecanismos de legitimação dos planos: (1) 1895-1930: planos de melhoramento urbano; (2) 1930-1950: planos de remodelação urbana; (3) 1950-1970: os planos diretores físico-territoriais; (4) 1970-1980: planos diretores de desenvolvimento local integrado e (5) a partir de 1988: planos diretores participativos. Em cada um desses períodos, Accioly (2008) busca reconhecer que vertentes teóricas do urbanismo fundam a visão e o projeto de cidade subjacentes aos planos: vertente funcionalista, vertente organicista ou vertente sistêmica.

O estudo de Accioly (2008) privilegia a relação entre as práticas de planejamento urbano e a expansão urbana da cidade de Fortaleza. Para a autora, as práticas de planejamento urbano, entendidas no contexto da expansão urbana de Fortaleza, foram definidas em três etapas: (1) os pioneiros, entre 1824 e 1932, representados pelas plantas de expansão, os códigos de posturas e as intervenções setoriais; (2) os planos de remodelação urbana, entre 1932 e 1963, expressos nos planos de melhoramento e no primeiro código urbano; (3) os planos diretores entre 1963 e 2000 (ACCIOLY, 2008, p.18).

A etapa dos pioneiros deixou marcas na morfologia da cidade até hoje, principalmente no traçado em xadrez, que constitui a matriz básica da cidade, caracterizada por um plano radial concêntrico superposto à malha ortogonal. Nesta etapa, "as ações urbanas eram orientadas pelas plantas de expansão urbana $\mathrm{e}$ pelos códigos de postura, que representavam a ideologia higienista sanitarista, fundada na medicina social" (ACCIOLY, 2008, p.105). Era o início das práticas de aformoseamento da capital, pautadas na influência francesa.

Já nesta época, destaca-se o papel do Estado na expansão urbana e na valorização desigual do espaço da cidade, pois ao implantar novas linhas de bondes, estradas de ferro e posteriormente rodovias, direcionava o crescimento da cidade, permitindo a constituição de chácaras de famílias ricas do interior ao longo e ao final das linhas, orientando a expansão da cidade para oeste (COSTA, 2009).

A etapa dos planos de remodelação urbana e de melhoramento urbano abrange o Plano de Remodelação e Extensão de Fortaleza (1933), proposto pelo urbanista Nestor Figueiredo, e o Plano Diretor de Remodelação e Expansão de Fortaleza (1947-1948), elaborado pelo urbanista José Otacílio Sabóia. O primeiro tinha influência do arquiteto Le Corbusier, ícone da arquitetura modernista/funcionalista, que defendia a separação das funções urbanas (habitação, trabalho, lazer e circulação) em forma de zoneamento, conforme as formulações presentes na Carta de Atenas (1933). O plano tinha como filosofia viária "a implantação de um sistema radio-concêntrico de vias principais, através de ruas periféricas e alargamento das radiais" (CODEF, 1979, p.28). Todavia, o plano nunca foi implementado, não chegando sequer a ser aprovado no Conselho Municipal. O segundo constituiu, segundo Accioly (2008, p.120), "a primeira experiência concreta de urbanismo em Fortaleza", chegando a ser aprovado na gestão do prefeito Acrísio Moreira da Rocha, mas nunca foi implementado, pois encontrou fortes resistências por parte da classe média e alta, que seria desapropriada para execução das obras previstas (abertura e alargamento do sistema viário e sistema de espaços verdes).

É importante lembrar que a década de 1930 é geralmente reconhecida como um marco a partir do qual Fortaleza consolida-se como principal centro econômico e demográfico do estado, para o qual convergem as atividades econômicas, o poder de gestão e os fluxos de migrantes expulsos pelas secas e/ou pela estrutura concentrada e desigual da propriedade privada no campo cearense (COSTA, 2009; SOUZA, 2009; SILVA, 1992; CODEF, 1979). 
A questão da habitação revela-se como parte da história da produção socioespacial na cidade de Fortaleza, explicitada no processo de favelização, que já era reconhecido por Castro (1977) na Planta da Cidade da Fortaleza de 1888, e intensificou-se a partir de 1930, como lembra Silva:

Esse "crescimento" de forma espontânea e desordenada deu lugar a aglomerações de edificações precárias na periferia da cidade. Data do inicio da década de 30 a origem desses aglomerados com características de favelas. Entre 1930-1955 surgiram as seguintes favelas na cidade: Cercado do Zé Padre (1930), Mucuripe (1933), Lagamar (1933), Morro do Ouro (1940), Varjota (1945), Meireles (1950), Papoquinho (1950), Estrada de Ferro (1954). (SILVA, 1992, p.29)

Assim, ficava "mais visível, a partir da década de trinta, o processo de diferenciação espacial e segregação residencial. A distribuição da população no espaço urbano de Fortaleza ficou nitidamente determinada pelo nível de renda" (COSTA, 2009, p.153).

Na década de 1950, Fortaleza experimentou acelerado crescimento populacional (de 270.169 em 1950 a 514.813 habitantes em 1960), fruto dos intensos fluxos migratórios, em resposta à estrutura agrária concentrada, às grandes secas de 1951 e 1958 e às enchentes de 1959 (COSTA, 2009). Outra mudança significativa na década de 1950 foi a formação de um novo segmento de classe média formada por professores universitários, executivos de empresas privadas e técnicos do setor público com a criação da Universidade Federal do Ceará (1955), da Superintendência de Desenvolvimento do Nordeste-SUDENE (1958) e a instalação de filiais de empresas privadas e sede dos órgãos federais (Departamento Nacional de Obras Contra as Secas-DNOCS, Banco do Nordeste do Brasil - BNB).

No contexto nacional, vivia-se a política desenvolvimentista de Juscelino Kubitscheck, pautada na industrialização e na concentração nas grandes cidades. A opção pela indústria automobilística para alavancar o setor de bens duráveis impôs a necessidade de implantação de muitas rodovias (articulado ao discurso nacional-desenvolvimentista da "integração nacional") e de profundas alterações morfológicas nas cidades brasileiras para atender ao transporte individual, com todas as suas externalidades negativas (congestionamento das infraestruturas, acidentes, poluição etc.). Ainda na esteira da industrialização, não se poderia deixar de mencionar a criação da Superintendência de Desenvolvimento do Nordeste - SUDENE em 1958, que captou recursos e os concentrou nas capitais, acirrando muitos dos problemas que visava (ao menos do discurso) combater. A política regional da SUDENE, consolidada no Grupo de Trabalho para o Desenvolvimento do Nordeste (GTDN) colocava Fortaleza na condição de polo de desenvolvimento urbano regional, fundamentando-se na Teoria dos Polos Regionais, que intensificou a concentração espacial de investimentos, contribuindo para a macrocefalia da capital.

Conforme Castro (1977), na década de 1960, Fortaleza tinha mais de 520 mil habitantes, mas apresentava uma área loteada suficiente para abrigar mais de dois milhões de pessoas. Isso apontava para o processo de expansão da malha urbana "aos saltos", deixando enormes vazios. Nesse quadro de mudanças, processa-se a terceira etapa das práticas de planejamento em Fortaleza, abrangendo três planos, que marcam três momentos de constituição da metrópole periférica: o Plano Diretor da Cidade de Fortaleza (1963), de caráter físico-territorial, fundamentado na vertente organicista (comprehensive planning); o Plano de Desenvolvimento Integrado da Região Metropolitana de Fortaleza (1972), característico dos planos diretores de desenvolvimento local integrado, fundamentado na vertente sistêmica e organicista (comprehensive planning); e o Plano de Desenvolvimento Urbano de Fortaleza (1992), que incorpora alguns elementos do planejamento urbano redistributivo ou politizado (mais em nível de discurso) e outros da vertente do comprehensive planning. Para análise detalhada desses planos, remete-se ao trabalho de Accioly (2008).

Interessa reter que o Plano Diretor da Cidade de Fortaleza (1963), proposto por Hélio Modesto, foi o primeiro a propor a integração das dimensões econômicas, sociais e administrativas no espaço urbano. Valorizou o centro como unidade de vizinhança e propôs a polinucleação integrada de centralidades comerciais e serviços. Foi o primeiro zoneamento residencial diferenciado em função do nível de renda da população, com índices urbanísticos específicos, que induziram/permitiram a verticalização em algumas áreas (Centro e Aldeota). Para Costa (2009, p.158), "a proposta de zoneamento desse plano, baseado na rede, é a oficialização da segregação socioespacial".

Esse plano sustentou-se numa concepção de metrópole regional industrial, consoante às proposições do GTDN. O plano representou uma proposta idealista de cunho reformista, típica da vertente do comprehen- 
sive planning, cuja estratégia era transformar Fortaleza em polo macrorregional por meio de uma política de desenvolvimento industrial (ACCIOLY, 2008). Todavia, o discurso competente que fundamentou esse plano não encontrou a correlação de forças políticas para construção de uma nova hegemonia ligada aos interesses do capital industrial, em substituição aos ditames do capital mercantil oriundo dos setores oligárquicos agroexportadores. Assim, apenas algumas poucas propostas que interessavam ao mercado imobiliário foram parcialmente realizadas:

[...] construção do trecho da Avenida Beira-Mar, voltando-se, finalmente, a cidade para o mar; construção da Avenida Perimetral, anel que contorna a cidade e ligando entre si os bairros da periferia (da Barra do Ceará ao Mucuripe); abertura da Avenida Luciano Carneiro, proporcionando melhores condições de acesso ao Aeroporto; elaboração de cartas aerofotogramétricas e ortofotocartas, cobrindo a área total do município, e implantação do Cadastro Imobiliário (CODEF, 1979, p. 40).

O quadro nacional da década de 1960 não poderia ser esquecido, já que em 1964 (Golpe Militar) há considerável ruptura nos pequenos avanços que os emergentes movimentos sociais urbanos estavam esboçando como resposta ao contexto de crescente precarização das condições sociais que caracterizou a urbanização brasileira, marcadamente a partir das décadas de 1950/1960. O crescimento econômico brasileiro no bojo de sua abertura aos capitais internacionais acabou forjando um "Estado do deixe-estar social" (FERREIRA e MOTISUKE, 2007), no qual, em relação à moradia, a "não política" habitacional, expressa nos cruéis expedientes de reprodução social como ocupações, cortiços, favelas e autoconstrução em loteamentos irregulares/clandestinos, se constituiu em importante estratégia do capital para rebaixar os custos com a reprodução da classe trabalhadora. As múltiplas estratégias desse perverso processo foram estudadas por Kowarick, que passou a chamá-lo "espoliação urbana" (KOWARICK, 1979). As grandes desigualdades acumuladas à medida que a urbanização perversa sem precedentes se consolidava no país começaram a conformar um contexto em que a questão urbana passou a figurar na agenda de debates e lutas sociais. Um marco reconhecido por vários estudiosos (MARICATO, 2001; CYMBALISTA, 2007; SOUZA, 2002) é o Movimento Nacional pela Reforma Urbana (MNRU).

Na esteira das estratégias de centralização do poder, o Governo Militar cria, por meio da Constituição Federal de 1967, as regiões metropolitanas, a serem estabelecidas posteriormente, com base em dados de polarização e integração. Este foi o caso de Fortaleza, cuja oficialização enquanto Região Metropolitana foi compulsória, ou seja, instituída por força legal, como já mencionado na Introdução. Já "no que tange à realidade socioespacial, significa dizer que sua institucionalização deu-se antes que o processo de metropolização se manifestasse" (SILVA, 2009, p.15). A institucionalização da RMF ocorreu com fins preventivos, configurando-se como uma "metropolização antecipada" (ACCIOLY, 2008).

Sob forte influência do Governo Federal, é elaborado o Plano de Desenvolvimento Integrado para a Região de Fortaleza - PLANDIRF, de 1972, pelo consórcio das empresas SERETE S.A., S. D: Consultoria de Planejamento e Jorge WiIheim Arquitetos Associados, tendo o apoio técnico e financeiro do SERFHAU (SOUZA, 2009). O principal objetivo do PLANDIRF era reforçar a condição de metrópole industrial e terciária (comércio, serviços e turismo), pautada na descentralização das atividades industriais para fins de consolidação da estrutura metropolitana. Todavia, essa consolidação restringia-se à integração dos demais municípios da RMF mediante obras viárias, sem qualquer proposta de cooperação entre estes e Fortaleza quanto à criação de serviços comuns e às funções urbanas compartilhadas (ACCIOLY, 2008, p.196).

Nesse período, chegou a ser criada a Autarquia Metropolitana de Fortaleza (AUMEF), que tinha como objetivo desenvolver o planejamento integrado da RMF, mas essa integração nunca se concretizou.

Como salientou Costa (2009), o PLANDIRF propunha a incorporação de novas áreas à cidade, com aberturas de vias e construção de pontes sobre o Rio Cocó, uma antiga barreira à expansão urbana na direção sudeste. Finalmente, "a cidade ultrapassaria a linha férrea Mucuripe-Parangaba e o Rio Cocó, incorporando o Sítio Cocó e as terras além do rio, o atual bairro da Água Fria" (COSTA, 2009, p.160). A figura 3 evidencia como a barreira do rio Cocó estava sendo rompida de forma a permitir a expansão do eixo sudeste, que se consolidaria nas décadas de 1980 e 1990.

Com base no PLANDIRF (escala metropolitana) foi elaborada a Lei de Uso e Ocupação do Solo de Fortaleza, lei $\mathrm{n}^{\circ} 4.486$, de 12/03/75. Essa lei contemplava os aspectos de zoneamento, sistema viário e 
parcelamento do solo. Propunha a acentuação do esquema radioconcêntrico da cidade, expandindo o sistema viário para o leste e para o sudeste, corroborando o "acelerado processo de especulação imobiliária abrindo-se novos loteamentos, sem nenhuma fiscalização do Poder Municipal e sem nenhuma infraestrutura, construindo-se residências de alto padrão em lotes de grandes testadas" (COSTA, 2009, p. 161). Essa lei foi substituída pela lei $\mathrm{n}^{\circ}$ 5.122-A de 13 de março de 1979, visando adequá-la às transformações na cidade e à regulamentação em nível federal da Lei de Parcelamento do Solo (Lei n ${ }^{\circ}$ 6.766/79). A lei n 5.122-A apresentava um zoneamento mais detalhado: zonas residenciais diferenciadas por densidade; zonas e corredores de uso misto; zonas de uso estritamente industrial; zonas de preservação ambiental e de interesse paisagístico; e zonas especiais de praia, renovação urbana e institucional (cf. figura 4). O zoneamento residencial proposto induzia claramente a expansão urbana para leste e sudeste, ao definir essas áreas como de alta densidade (ZR-3), diferentemente da lei aprovada em 1975 (COSTA, 2009).

Conforme demonstra Accioly (2008, p.208), o PLANDIRF, bem como os demais planos formulados não referenciaram as práticas do Estado nem foram reconhecidos pelos agentes produtores do espaço. Todavia, as leis de uso e ocupação do solo, atendendo à lógica do mercado imobiliário, efetivamente "interferiram no modo de vida da população e na divisão socioespacial, promovendo uma valorização diferenciada entre as áreas da cidade”. Essa compreensão remete à ideia defendida por Villaça $(1999 ; 2005)$ de que o zoneamento é uma modalidade de planejamento urbano lato sensu diferente do planejamento strictu sensu (plano diretor), correspondendo a interesses e soluções específicos das elites brasileiras. Para o autor, as leis específicas de zoneamento (por exemplo, as leis de uso e ocupação do solo), separadas dos planos diretores, são operacionais, autoaplicáveis, aprovadas nas Câmaras Municipais e efetivamente executadas, enquanto os planos diretores "tem sido fundamentalmente discurso, cumprindo missão ideológica de ocultar os problemas das maiorias urbanas e os interesses dominantes na produção do espaço urbano" (VILLAÇA, 1999, p.222).

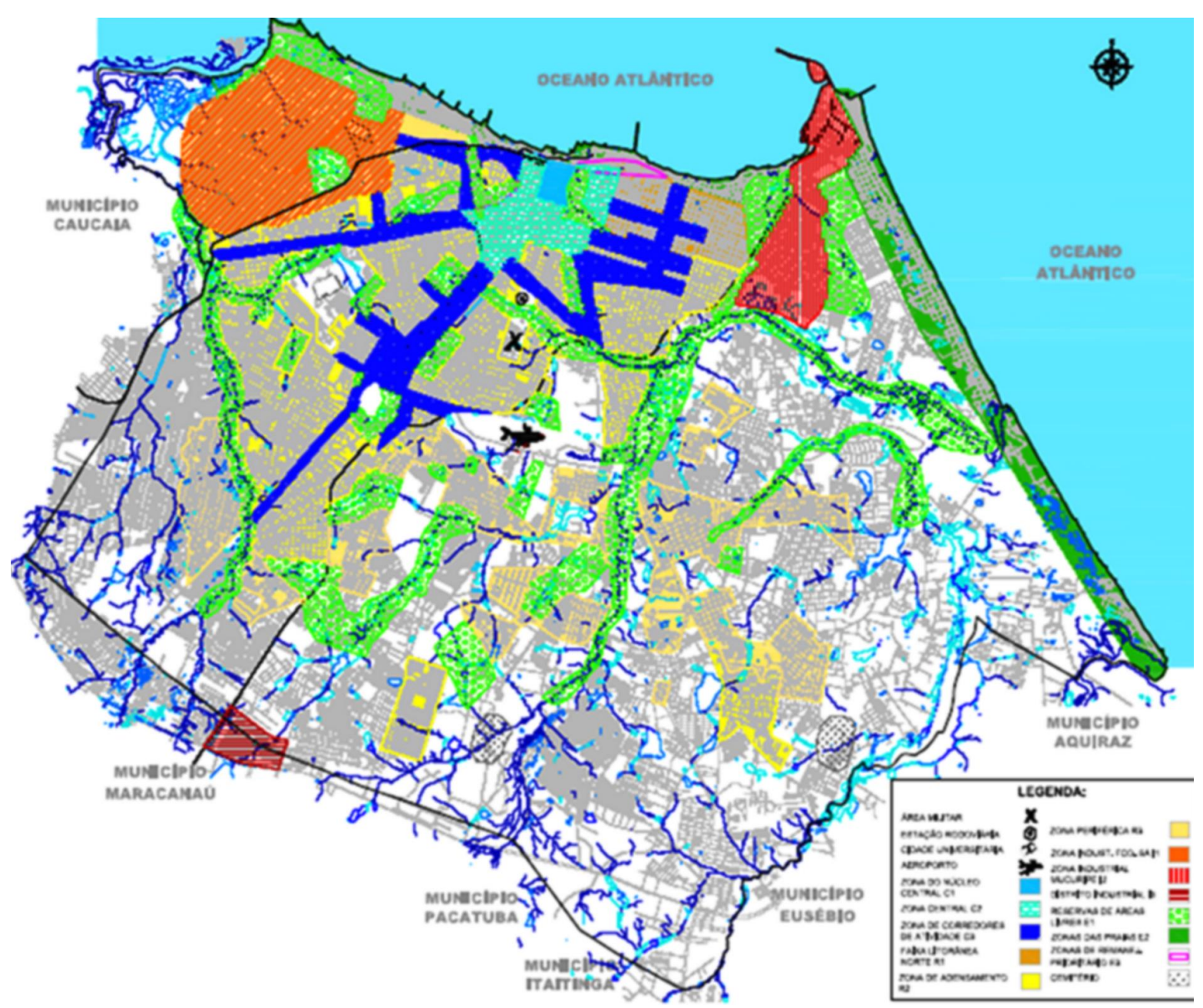

Figura 3 - Mapa de zoneamento do Plano Diretor Físico de Fortaleza (1972) Fonte: ACIOLLY, 2008. 


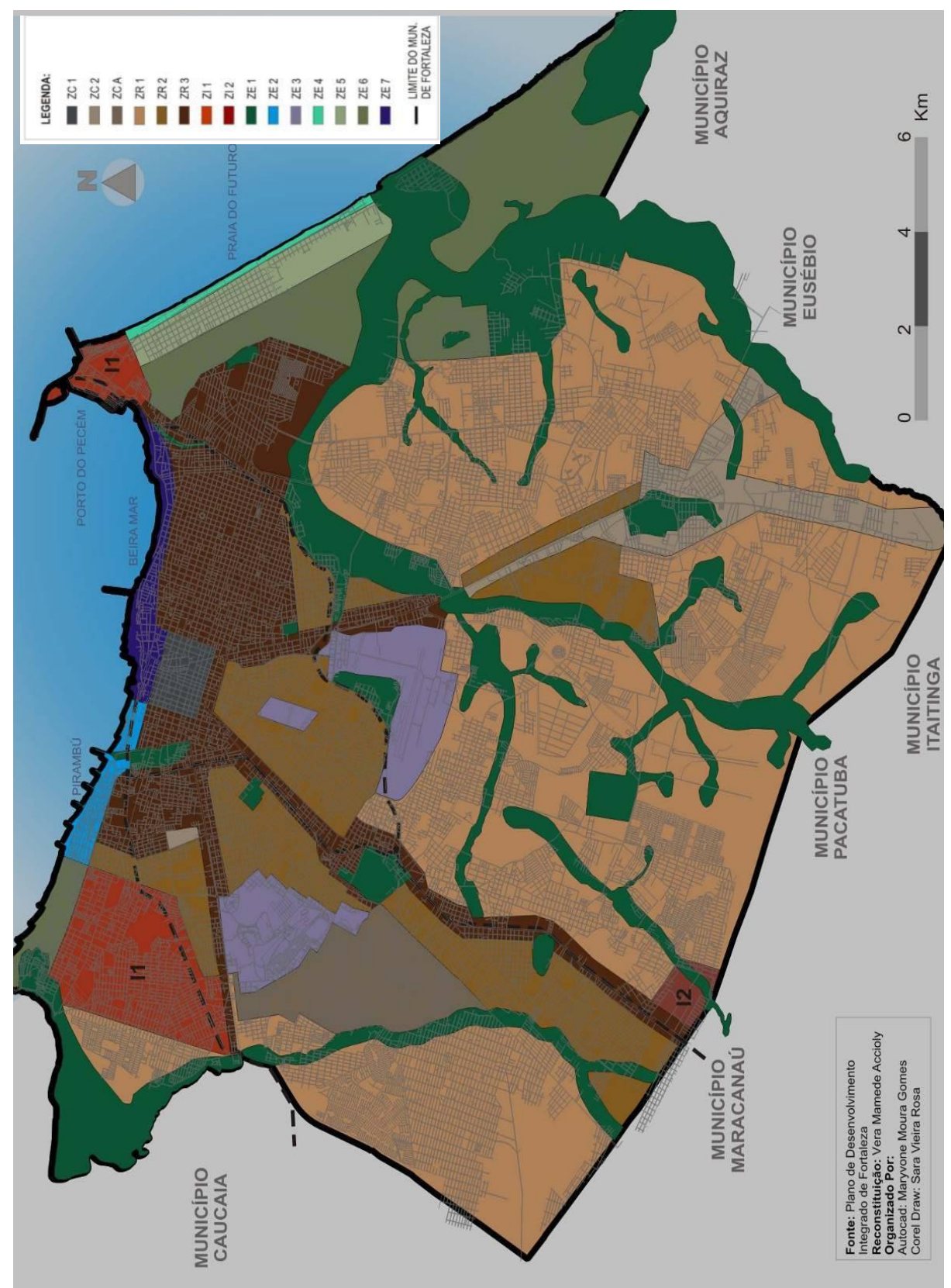

Figura 4 - Lei de Uso e Ocupação do Solo de Fortaleza (1979)

Fonte: ACIOLLY, 2008.

Retomando a escala nacional, nas décadas de 1970 e 1980 destacou-se a questão urbana na agenda do debate político, com o fortalecimento do MNRU. Entre as principais conquistas do MNRU em articulação com outros movimentos sociais durante a década de 1980, no tocante à política urbana, foi a inserção do capítulo da política urbana na Constituição Federal de 1988 (artigos 182 e 183), resultado da Emenda Constitucional de Iniciativa Popular de Reforma Urbana, subscrita por mais de 130.000 eleitores (MARICATO, 2001). Todavia, em que pese a grande importância dessa conquista, os movimentos sociais e os estudiosos da questão urbana reconhecem as limitações do texto constitucional, principalmente o fato de vincular a aplicação dos instrumentos que garantem o cumprimento da função social da propriedade e da cidade à existência de uma lei federal e do plano diretor. Assim, a falta de autoaplicabilidade dos dispositivos constitucionais representou um grande entrave às mudanças concretas nos rumos de nossas cidades.

A partir do texto constitucional, o plano diretor passa a figurar como "instrumento básico da política de desenvolvimento e de expansão urbana" (art. 182, § $1^{\circ}$ ). É importante ressaltar a limitação que os deputados constituintes impuseram ao estabelecerem que o princípio da função social da propriedade seria aplicável em municípios com mais de 20 mil habitantes, obrigados a elaborar um plano diretor, impondo-se a dependência 
de conhecimento técnico e de ação política das gestões municipais para definir os critérios para o cumprimento da função social da propriedade. Fato relevante é que quando a Constituição Federal foi promulgada apenas 50\% dos municípios brasileiros tinham mais de 20 mil habitantes e em 2000, após a criação de novos municípios, esse número caiu para $30 \%$.

No contexto de emergência de novos planos diretores, é aprovado o Plano Diretor de Desenvolvimento Urbano (PDDU-FOR) pela lei $n^{\circ} 7.061 / 92$, sendo o primeiro plano a ter participação da equipe técnica da própria prefeitura em sua elaboração, contando com apoio de consultoria externa. Conforme Accioly (2008), a concepção de planejamento urbano presente no PDDU-FOR não foi uma ruptura em relação às práticas anteriores, ao associar a vertente do comprehensive planning à vertente redistributivista e aspectos das vertentes do novo urbanismo. O plano tentou incorporar elementos do ideário da Reforma Urbana, mas a correlação de forças locais limitou consideravelmente essa experiência.

O PDDU-FOR propunha o zoneamento da cidade (cf. figura 5) em três macrozonas: (1) macrozona urbanizada - área atendida integralmente pela rede de abastecimento de água e parcialmente pela rede de esgoto, onde se concentravam infraestruturas, atividades e população; (2) macrozona adensável - área atendida parcialmente pela rede de abastecimento de água e sem rede de esgoto, onde se verificava tendência de expansão urbana; (3) macrozona de transição - área não adensada, sem infraestrutura de água nem de esgoto, na franja rural-urbana.

Quanto ao sistema viário, o PDDU-FOR mantinha o padrão de articular a matriz radioconcêntrica e a ortogonal. Dessa forma, propunha-se um subsistema viário estrutural (vias expressas e vias arteriais) e um subsistema viário de apoio (vias comerciais, vias coletoras e vias locais). O PDDU-For não foi posto em prática nos aspectos que incorporavam o ideário da Reforma Urbana, fragilizando o processo de planejamento na cidade, como mostra Accioly (2008):

A Lei de Uso e Ocupação do Solo, único instrumento regulamentado, não traduz a concepção redistributiva do plano e, em muitos aspectos, constitui uma adaptação da Lei 5 122-A, ainda seguindo os princípios do Plandirf e das leis complementares que beneficiam os interesses imobiliários. Quanto aos demais instrumentos jurídicos, financeiros e econômicos, que teriam o efeito redistributivo e promoveriam a justiça social e os direitos à cidade, não foram regulamentados. Na realidade o plano não teve o reconhecimento das esferas públicas e privadas, no entanto a Luos [...] teve papel incisivo na direção e natureza da expansão urbana. (ACCIOLY, 2008, p.256)

Após a promulgação da Constituição Federal de 1988, tida como constituição cidadã, mesmo no contexto de redemocratização do país e de descentralização administrativa, teve início a longa via crucis da lei que regulamentaria o capítulo da política urbana, aprovada somente 13 anos após a Constituição Federal, ficando conhecida como Estatuto da Cidade (lei n 10.257/2001). Conforme Rolnik (2001), o Estatuto da Cidade estruturou-se em torno do reconhecimento de três problemas-chave da questão urbana brasileira: a irregularidade fundiária (favelização), a especulação imobiliária (retenção de vazios urbanos) e a cidade tecnocrática (falta de participação popular). Para cada problema-chave, elegeu-se uma bandeira de luta e definiram-se instrumentos específicos para cada uma delas: regularização fundiária, função social da propriedade e gestão democrática da cidade.

O contexto pós-aprovação do Estatuto da Cidade era de otimismo por parte dos movimentos sociais bem como dos setores acadêmicos comprometidos com as lutas sociais. Em Fortaleza, estava no momento de revisar o Plano Diretor de Desenvolvimento Urbano (PDDU), vigente desde 1992. Assim, ainda em 2001, cedendo às pressões da sociedade civil, iniciou-se o processo de revisão do plano diretor, que se arrastaria até 2009, quando de sua aprovação pela Lei Complementar 062/2009. Um minucioso resgate desse processo de revisão foi objeto de estudo de Machado (2010). Esse estudo revela que o processo de revisão foi marcado por conflitos de interesses dos agentes envolvidos: 1) polo estatal (dividido internamente entre um segmento ligado à gestão anterior - SEINF e SEMAM - e um segmento mais progressista identificado com a nova gestão - SEPLA e HABITAFOR); 2) polo popular (entidades e movimentos que compõem a Rede Nuhab: Movimento dos Conselhos Populares, Federação de Bairros e Favelas, Movimento de Luta nos Bairros, Cáritas, Comunidades Eclesiais de Base, Coordenação de Movimentos Populares, Movimento Ambientalista, dentre outros); e 3) polo empresarial (liderado pelo SINDUSCON). 
A forte articulação do grupo de empresários liderado pelo SINDUSCON, ainda que só tenha aparecido no final do processo, teve peso suficiente para mudar os rumos das negociações e fragilizar as conquistas do chamado "polo popular". Um dos principais focos de conflitos foi a delimitação e regulamentação das ZEIS.

Para Souza (2002), as ZEIS são importante instrumento para promover a "inversão de prioridades", passando-se a investir na parte da cidade que nunca havia sido reconhecida pelo planejamento tecnocrático. Rolnik (2001) reconhece as ZEIS como o instrumento síntese das diretrizes e princípios norteadores do Estatuto da Cidade, pois enfrentam os três problemas-chave da questão urbana brasileira: o combate à especulação imobiliária, impedindo-se o remembramento de lotes e consolidando-se áreas de ocupação sob pressão do setor imobiliário formal; a promoção da regularização fundiária graças à flexibilização dos índices urbanísticos; a adoção de práticas de gestão democrática e participativa mediante a formação de conselhos locais que atuam nas diferentes fases de sua implementação.

O PDPFor estrutura o planejamento da cidade em dez políticas setoriais: habitação e regularização fundiária, terras públicas, meio ambiente, saneamento ambiental, defesa civil, mobilidade, proteção do patrimônio cultural, desenvolvimento econômico, turismo, e integração metropolitana. Cada política setorial deveria ser regulamentada posteriormente por meio da elaboração de um plano setorial, com participação popular. Todavia, até o momento de elaboração deste texto, dos planos setoriais complementares, apenas o Plano Local de Habitação de Interesse Social (PLHIS-For) vem sendo realizado. Todos os prazos definidos na lei do PDPFor já foram vencidos e o plano continua sem aplicação. Isso é agravado pelo fato de que a Lei de Uso e Ocupação do Solo (LUOS) ainda não foi atualizada, continuando em vigência a LUOS de 1996, totalmente incoerente com o novo plano.

Com relação ao ordenamento territorial, o PDPFor definiu um macrozoneamento e zonas especiais. O macrozoneamento se subdivide em dois: (1) macrozona de ocupação urbana - corresponde às porções do território caracterizadas pela significativa presença do ambiente construído, a partir da diversidade das formas de uso e ocupação do solo e se subdivide nas seguintes zonas: I - Zona de Ocupação Preferencial 1 (ZOP 1); II - Zona de Ocupação Preferencial 2 (ZOP 2); III - Zona de Ocupação Consolidada (ZOC); IV - Zona de Requalificação Urbana 1 (ZRU 1); V - Zona de Requalificação Urbana 2 (ZRU 2); VI - Zona de Ocupação Moderada 1 (ZOM 1); VII - Zona de Ocupação Moderada 2 (ZOM 2); VIII - Zona de Ocupação Restrita (ZOR); IX - Zona da Orla (ZO); e (2) macrozona de proteção ambiental - é composta por ecossistemas de interesse ambiental, bem como por áreas destinadas à proteção, preservação, recuperação ambiental e ao desenvolvimento de usos e atividades sustentáveis, subdividindo-se nas seguintes zonas: I - Zona de Preservação Ambiental (ZPA); II - Zona de Recuperação Ambiental (ZRA); III - Zona de Interesse Ambiental (ZIA).

Já as Zonas Especiais, de acordo com o art. 122, compreendem áreas do território que exigem tratamento especial na definição de parâmetros reguladores de usos e ocupação do solo, sobrepondo-se ao zoneamento. As ZEIS, como já mencionado, foram o principal foco de conflitos no processo de elaboração do PDPFor e o será mais ainda nas tentativas de sua efetiva implementação. Nos arts. 124 a 133, o PDPFor prevê uma classificação das ZEIS em três tipos: tipo 1 (ocupações/favelas), tipo 2 (conjuntos habitacionais e loteamentos clandestinos/irregulares) e tipo 3 (vazios urbanos / terrenos subutilizados), conforme figura 7. A espacialização das ZEIS torna evidente o subdimensionamento do problema habitacional em Fortaleza, que, segundo dados ainda não oficiais, está em vias de atingir o alarmante nível de $40 \%$ de favelização (PEQUENO, 2011). Ainda assim, ter essas primeiras 135 áreas delimitadas oficialmente (45 ZEIS 1; 56 ZEIS 2 e 34 ZEIS 3) já abre possibilidades reais de controle social dos rumos da política urbana em articulação com a política habitacional no município. 


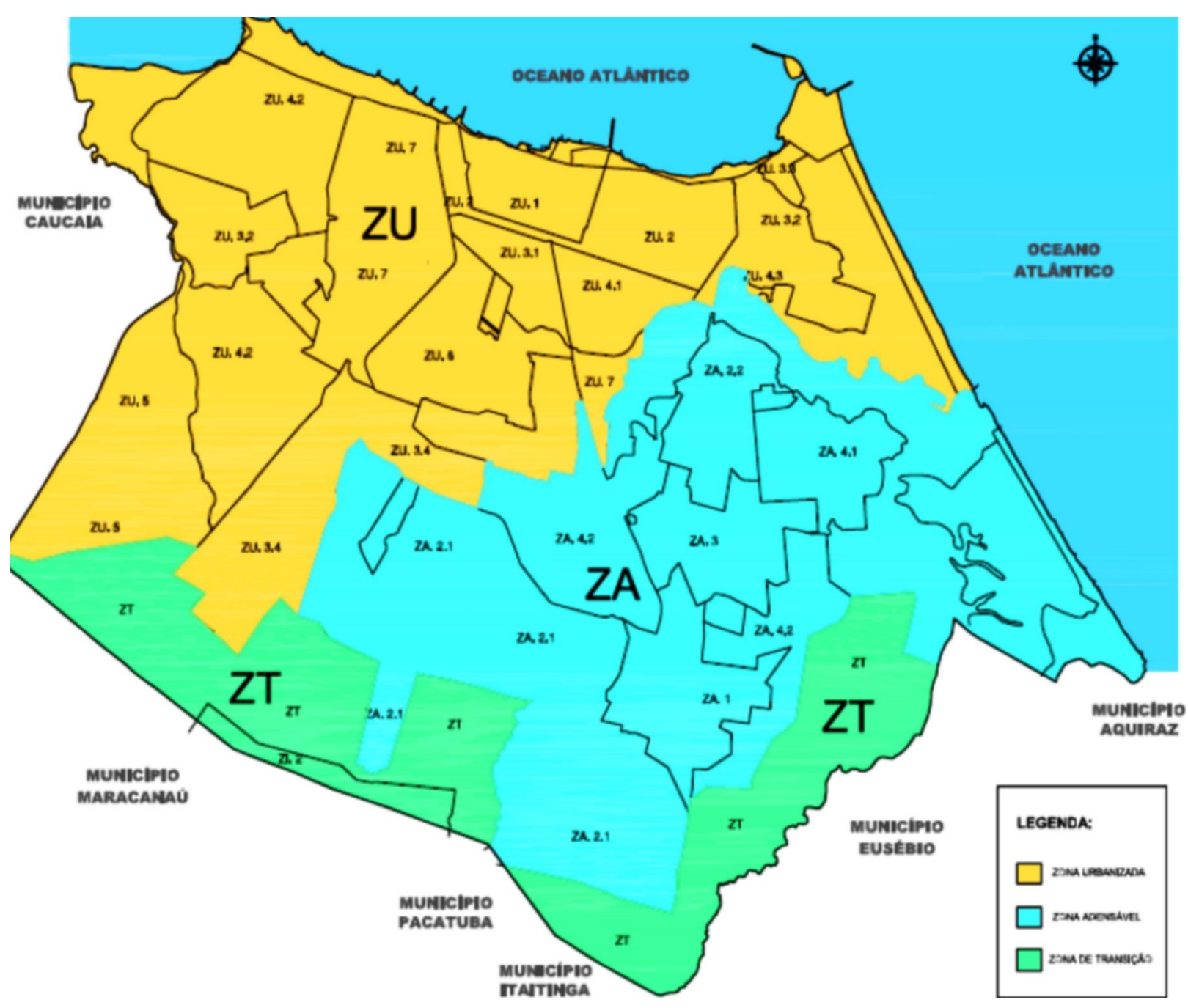

Figura 5 - Mapa de Zoneamento do Plano Diretor de Desenvolvimento Fortaleza (PDDU) de 1992

Fonte: ACIOLLY, 2008.

Um dos principais pontos de fragilização das ZEIS em Fortaleza foi o fato de seu mapeamento ter sido divulgado em 2006, mas a aprovação do PPDFor só ter ocorrido em 2009. Vale ressaltar que a gestão municipal "congelou" as ZEIS favela já em 2006, não permitindo remembramento de lotes ou qualquer aprovação de novos projetos, mas não "congelou" as ZEIS vazio. O resultado perverso é que os proprietários e empreendedores imobiliários apressaram-se em aprovar projetos nas áreas delimitadas como ZEIS vazio, reduzindo o já pequeno montante de terras disponíveis para HIS. 

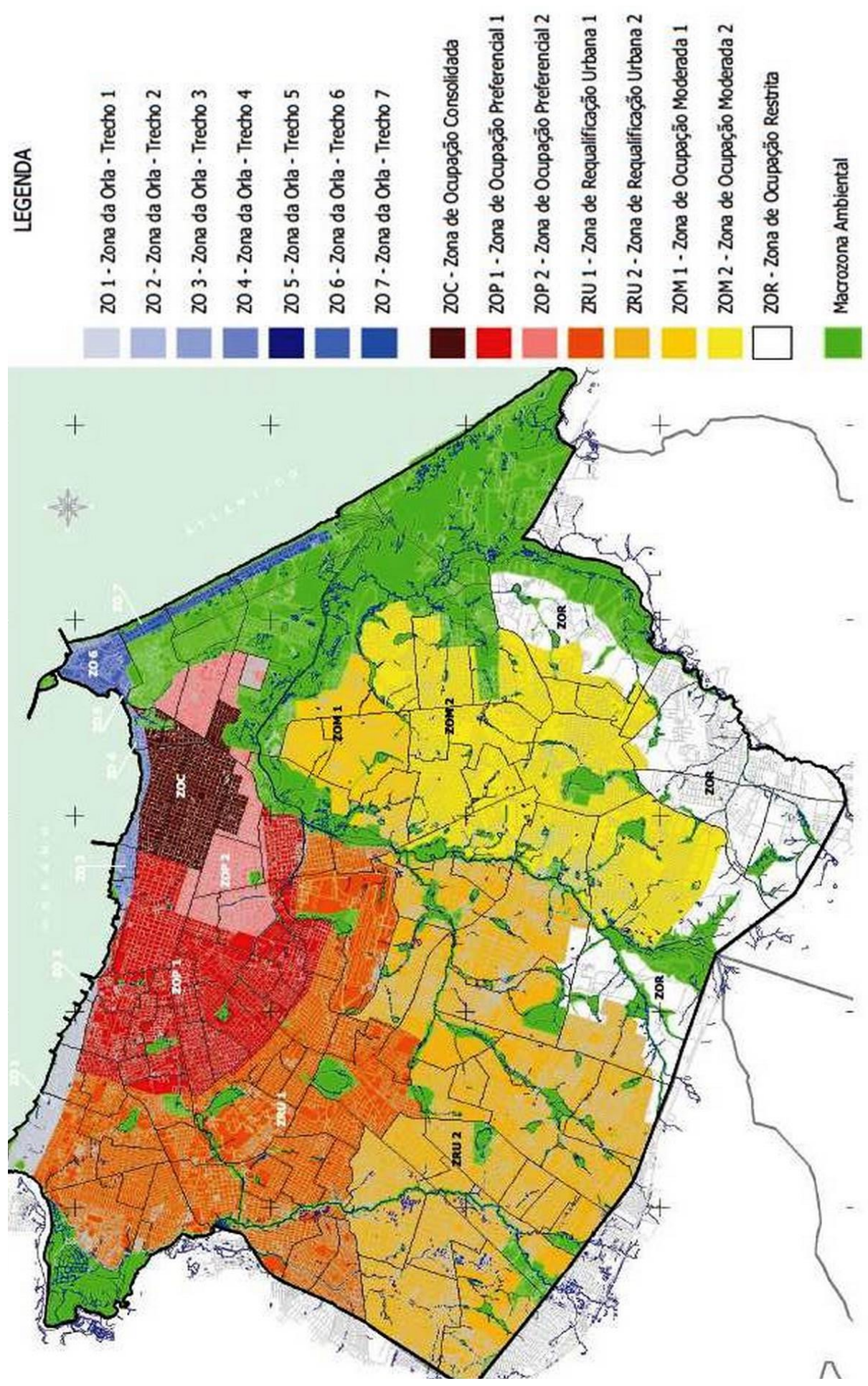

Figura 6 - Zoneamento urbano do PDPFor (2009)

Fonte: FORTALEZA, 2009 


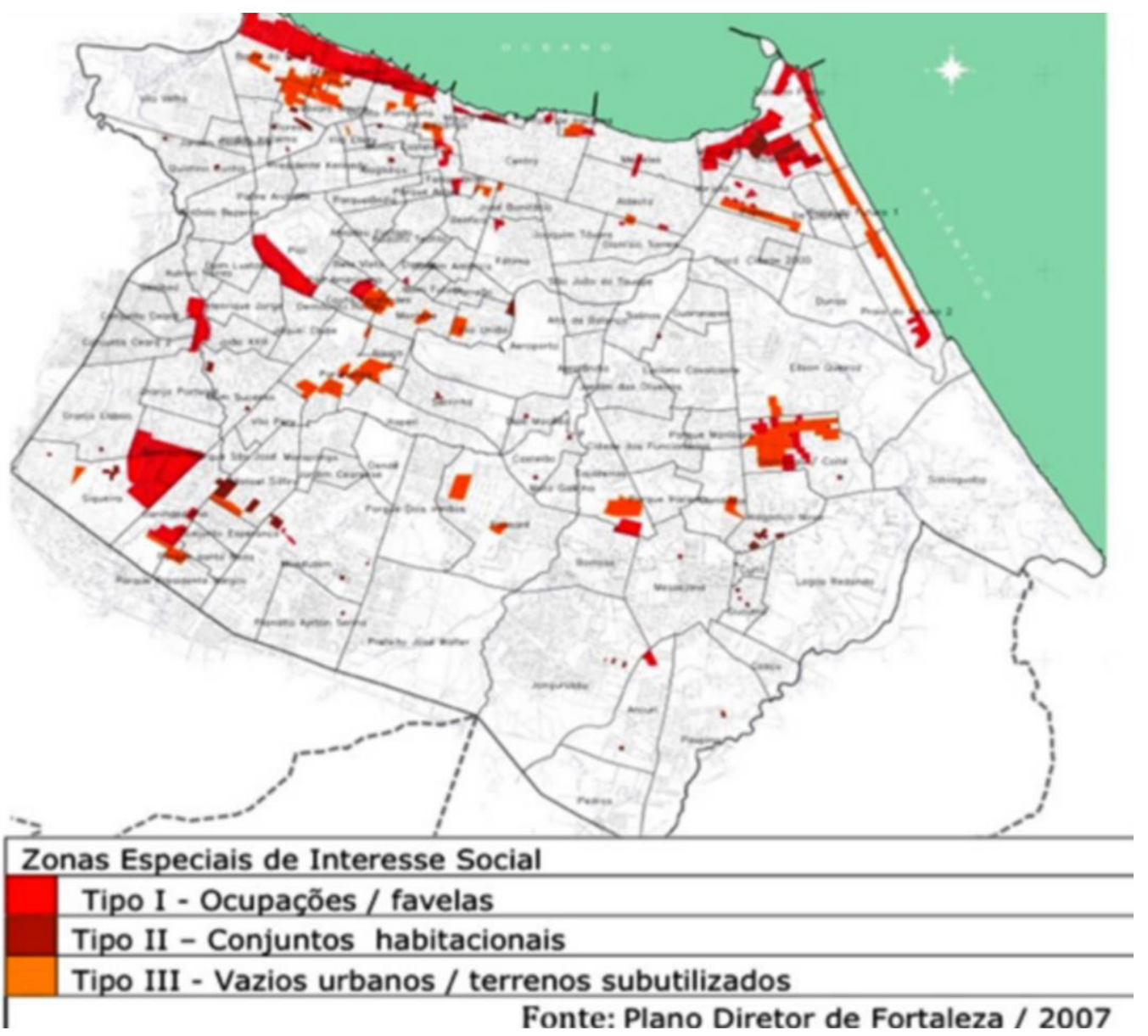

Figura 7 - Zonas Especiais de Interesse Social do PDPFor Fonte: FORTALEZA, 2009.

Reconstruir a história de Fortaleza a partir dos processos de planejamento permitiu deslindar a produção de um espaço marcado pelo histórico planejamento descolado da realidade de grande parte da cidade - a cidade real, reconhecida por Maricato (2000) como um "lugar fora das ideias", dialeticamente articulado à cidade ideal/legal, produzida por "ideias fora do lugar". Segundo Accioly (2008), os planos diretores, enquanto discurso competente e ideologizado, se configuraram como concepções de cidades idealizadas, compatíveis com as ideologias das políticas regionais e urbanas nacionais, sem se constituírem em efetivo plano de gestão municipal nem terem o reconhecimento dos agentes produtores do espaço. Sua formulação não teve como referência a realidade local, e, portanto, não atenderam às condições políticas, econômicas, socioespaciais e financeiras de Fortaleza, evidenciando a dissociação entre diagnóstico, diretrizes e instrumentos.

\section{CONSIDERAÇÕES FINAIS}

A partir do breve quadro traçado quanto à expansão metropolitana de Fortaleza, sinaliza-se que ela foi conduzida pelos grandes proprietários fundiários e incorporadores imobiliários em diferentes articulações com o Estado. Por exemplo, a escolha do tipo de loteamento a ser implantado em cada localização dependia da informação privilegiada que os loteadores tinham em relação à implantação de infraestrutura por parte do Estado (especialmente a viária) ou mesmo da pressão que esses loteadores exerciam para direcionar esses investimentos, já que muitos loteadores participaram da máquina pública. As negociações de terrenos entre Estado e grandes proprietários fundiários (especuladores) para construção de equipamentos polarizadores que valorizariam as terras desses proprietários - como foi o caso do setor sudeste - também marcou o processo de expansão da cidade. Além disso, a legislação elitista e segregadora que regulou a implantação de loteamentos (códigos de posturas, código urbano e LUOS) foi aplicada de forma descolada dos discursos e práticas dos planos diretores, confirmando o pensamento de Villaça (1999) de que as leis específicas de zoneamento e parcelamento do solo, separadas dos planos diretores, constituem o principal instrumento 
legal das elites brasileiras para garantir a segregação socioespacial.

Essa análise buscou evidenciar que a propriedade privada da terra é o fundamento dos processos de especulação imobiliária e de segregação socioespacial que marcam a produção da cidade capitalista.

Destacou-se que o vetor habitacional de metropolização foi determinante nas dinâmicas de expansão metropolitana. Considerando a caracterização das formas diferenciadas de moradia associadas aos diferentes agentes sociais que as produzem em Fortaleza (mercado, Estado e moradores/sujeitos sociais), ressalta-se a importância de sua compreensão articulada enquanto um dos elementos de estruturação da metrópole (PEQUENO, 2008). Tomando a habitação como indicador da estrutura da metrópole, destacam-se as marcas socioespaciais deixadas por esses três agentes: (1) o Estado concentrou a localização dos conjuntos habitacionais no espaço periférico ao oeste e sudoeste, configurando processo de redistribuição de população especialmente concentrado nas décadas de 1970 e 1980 e induzindo a conurbação entre Fortaleza, Caucaia e Maracanaú; (2) o mercado imobiliário formal manteve-se concentrado espacial e socioeconomicamente, tendo por principais vetores o leste (predominantemente verticalizado) e o sudeste (predominantemente horizontal) da metrópole e alguns poucos focos de "bairros emergentes"; e (3) a população excluída da oferta de moradias (pelo mercado ou pelo Estado) intensificou o processo de favelização nos corredores de degradação socioambiental (PEQUENO, 2002), induzindo nova forma de conurbação a partir de 1990, com o transbordamento de miséria e exclusão social para os municípios vizinhos.

\section{REFERÊNCIA BIBLIOGRAFICA}

ACCILLY, Vera Mamede. Planejamento, Planos Diretores e expansão urbana: Fortaleza 1960-1992. $295 \mathrm{fl}$. Tese - Universidade Federal da Bahia. Programa de pós-graduação em Arquitetura e Urbanismo. Salvador, 2008.

AMORA, Zenilde Baima. O espaço urbano cearense: breves considerações. In: AMORA, Zenilde Baima (Org.). O Ceará: enfoques geográficos. Fortaleza: Funece, 1999.

ASCHER, François. Metropolização e metápoles. In: ASCHER, François. Metapolis: acerca do futuro da cidade. [1 ${ }^{a}$ ed., 1995]. Oeiras: Celta, 1998. p. 3-21.

CASTRO, José Liberal de. Fatores de localização e de expansão da cidade de Fortaleza. Fortaleza: Conselho Regional de Engenharia, Arquitetura e Agronomia, 1977.

COORDENADORIA DE DESENVOLVIMENTO URBANO DE FORTALEZA - CODEF. Fortaleza: evolução urbana (1603 / 1979). Fortaleza: CODEF / IOCE, 1979.

CORRÊA, Roberto Lobato. Rede urbana. São Paulo: Ática, 1989.

COSTA, Maria Clelia Lustosa. Cidade 2000 - expansão urbana e segregação espacial em Fortaleza. (Dissertação de Mestrado em Geografia Humana). São Paulo: FFLCH/USP, 1988.

COSTA, Maria Clelia Lustosa. Planejamento e Expansão Urbana. In: DANTAS, Eustógio Wanderley Correia; SILVA José Borzacchielo da; e COSTA, Maria Clélia Lustosa. De cidade à metrópole: (trans)formações urbanas em Fortaleza. Fortaleza: Edições UFC, 2009, p.143-185.

CYMBALISTA, Renato. Instrumentos de planejamento e gestão da política urbana: um bom momento para uma avaliação. In BUENO, Laura M.; CYMBALISTA, Renato (Org.). Planos diretores municipais: novos conceitos de planejamento territorial. São Paulo: Anna Blume: Instituto Pólis: PUCCAMP, 2007, pp. 25-32.

DANTAS, Eustógio Wanderley Correia. Da Fortaleza à região metropolitana. In COSTA, Maria Clélia Lustosa e DANTAS, Eustógio Wanderley Correia (orgs.) Vulnerabilidade socioambiental na região metropolitana de Fortaleza. Fortaleza: Edições UFC, 2009.

DANTAS, Eustógio Wanderley Correia; SILVA, José Borzacchiello da. In COSTA, Maria Clélia Lustosa e DANTAS, Eustógio Wanderley Correia (orgs.) Vulnerabilidade socioambiental na região metropolitana de Fortaleza. Fortaleza: Edições UFC, 2009.

FERREIRA, João S. W. e MOTISUKE, Daniela. A efetividade da implementação das Zonas Especiais de Interesse Social no quadro habitacional brasileiro: uma avaliação inicial. In BUENO, Laura M.; CYMBALISTA, Renato (Org.). Planos diretores municipais: novos conceitos de planejamento territorial. São Paulo: Anna Blume: Instituto Pólis: PUCCAMP, 2007, pp. 33-88. 
FUCK JUNIOR, Sérgio César de França. Expansão Urbana e Segregação Espacial no Sudeste do Município de Fortaleza. 2002. Dissertação. (Mestrado Acadêmico em Geografia) - Centro de Ciências e Tecnologia, Universidade Estadual do Ceará. Fortaleza, 2002.

IBGE. Região de influência das cidades - REGIC 2007. Rio de Janeiro: IBGE, 2008.

KOWARICK, Lucio. A espoliação urbana. Rio de Janeiro: Paz e Terra. 1979.

LENCIONI, Sandra. O processo de metropolização do espaço: uma nova maneira de falar da relação entre metropolização e regionalização. In: SCHIFFER, B. (Org.). Globalização e estrutura urbana. São Paulo: Hucitec, 2004. p. 153-165.

LENCIONI, Sandra. Reconhecendo metrópoles: território e sociedade. In: SILVA, Catia Antonia; FREIRE, Désirée Guichard; OLIVEIRA, Floriano José Godinho. Metrópole: governo, sociedade e território. Rio de Janeiro: DP\&A, 2006.

LENCIONI, Sandra. Concentração e centralização das atividades urbanas: uma perspectiva multiescalar. Reflexões a partir do caso de São Paulo. Revista de Geografia Norte Grande, n. 39, 2008, p. 7-20.

LENCIONI, Sandra. A metamorfose de São Paulo: o anúncio de um novo mundo de aglomerações difusas. Revista Paranaense de Desenvolvimento, Curitiba, n.120, jan./jun. 2011, p.133-148.

LIMA, Luiz Cruz. Redes de integração do território cearense: dos caminhos da pecuária às estradas virtuais. In: SILVA, José B. Da; CAVALCANTE, Tércia; DANTAS, Eustógio. (Org.). Ceará: Um Novo Olhar Geográfico. 1a ed. Fortaleza: Edições Demócrito Rocha, 2005, v. 1, p. 33-50.

MACHADO, Eduardo Gomes. Planejamento urbano, democracia e Participação popular: o caso da revisão do Plano Diretor de Fortaleza (2003-2008). 450f. Tese. Universidade Federal do Ceará (Programa de Pós-Graduação em Sociologia). Fortaleza, 2010.

MARICATO, Ermínia. Brasil, cidades: alternativas para a crise urbana. Petrópolis: Vozes, 2001.

52 PEQUENO, Luis Renato Bezerra; MOLINA, Arthur. Análise socio-ocupacional da estrutura intra-urbana da Região Metropolitana de Fortaleza. In PEQUENO, Luis Renato Bezerra (org.). Como anda Fortaleza. Rio de Janeiro: Letra Capital: Observatório das Metrópoles, 2009.

PEQUENO, Luis Renato Bezerra (org.). Como anda Fortaleza. Rio de Janeiro: Letra Capital: Observatório das Metrópoles, 2009.

PEQUENO, Luis Renato Bezerra. Desenvolvimento e degradação do espaço intra-urbano de Fortaleza, Tese de Doutorado apresentada à FAUUSP, São Paulo, 2002.

PEQUENO, Luis Renato Bezerra. Análise sócio-ocupacional da estrutura intra-urbana da Região Metropolitana de Fortaleza. Mercator - Revista de Geografia da UFC. Fortaleza, ano 07, número 13, 2008.

PEQUENO, Luis Renato Bezerra. Classificação dos processos segundo os agentes da produção habitacional. Nota de aula da disciplina "Programas Habitacionais de Interesse social e Desenvolvimento de Projetos", mar. 2011.

RIBEIRO, Luiz César de Queiroz (org.). Hierarquização e identificação dos espaços urbanos. Rio de Janeiro: Letra Capital: Observatório das Metrópoles, 2009.

RIBEIRO, Luiz César de Queiroz. Níveis de Integração dos Municípios Brasileiros em RMs, RIDEs e AUs à Dinâmica da Metropolização. Rio de Janeiro: Observatório das Metrópoles, 2012.

ROLNIK, Raquel, Guia do Estatuto da Cidade, Câmara dos Deputados, Brasília, 2001.

RUFINO, Maria Beatriz Cruz. Incorporação da metrópole: centralização do capital no imobiliário e nova produção de espaço em Fortaleza. Tese (Universidade Estadual de São Paulo), São Paulo, 2012.

SANTOS JUNIOR, Orlando Alves dos (Coord.). Arranjos institucionais de Gestão Metropolitana. Rio de Janeiro: IPPUR, 2009. (Projeto Observatório das Metrópoles - Relatório de Pesquisa).

SILVA, José Borzacchiello da. Os incomodados não se retiram. Fortaleza: Multigraf Editora, 1992.

SILVA, José Borzacchiello da. Formação socioterritorial urbana. In: DANTAS, Eustógio Wanderley Correia; SILVA José Borzacchielo da; e COSTA, Maria Clélia Lustosa. De cidade à metrópole: (trans)formações urbanas em Fortaleza. Fortaleza: Edições UFC, 2009, p. 87-141.

SOUZA, Maria Salete de. Análise da estrutura urbana. In DANTAS, Eustógio Wanderley Correia; SILVA José Borzacchielo da; e COSTA, Maria Clélia Lustosa. De cidade à metrópole: (trans)formações urbanas 
em Fortaleza. Fortaleza: Edições UFC, 2009, p.13-86.

SOUZA, Marcelo Lopes de. Mudar a cidade. Rio de Janeiro, Bertrand Brasil, 2002.

SOUZA, Marcelo Lopes de. Introdução: a "nova geração" de movimentos sociais urbanos - e a nova onda de interesse acadêmico pelo assunto. Cidades, Presidente Prudente, v. 6, n. 9, p. 9-26, jan./jun., 2009.

VILLAÇA, Flávio. Espaço intra-urbano no Brasil. São Paulo: Studio Nobel: FAPESP, 2001.

VILLAÇA, Flávio. Uma contribuição para a história do planejamento urbano no Brasil. In DEÁK, Csaba; SHIFFER, Sueli Ramos. O processo de urbanização no Brasil. São Paulo: Edusp, 1999, p. 169-243.

Trabalho enviado em novembro de 2012

Trabalho aceito em janeiro de 2013 